\title{
Implementing Blended Learning in Teaching English at Higher Education in Industrial Revolution 4.0
}

\author{
Dian Anggraini \\ University of Putra Indonesia YPTK Padang, Indonesia \\ diananggraini.unp@gmail.com
}

\begin{abstract}
This research aims to find the effect of blended learning toward student's achievement at higher education. This strategy is expected to contribute to be better in teaching at UPI "yptk" Padang. The research is an experiment which population consists of the students academic year of 2018/2019. Instrument is used in collecting data of this research was treatment materials in the form of blending learning and data collection instruments. The results of this research revealed a significant influence on the students' achievement.
\end{abstract}

Keywords: Blended Learning, Higher Education, Industrial Revolution 4.0

\section{Introduction}

Industrial is influenced by technological change and innovation. This is known as the industrial revolution. In the industrial revolution 1.0 was caused by mechanization, the industrial revolution 2.0, the use of electrical energy and the industrial and electronic 3.0 revolution and automation. All of these industrial revolutions affected the labor market and the education system. As a result of these changes, several professions and jobs were lost. At present, due to the development of digitization and robotics, we are facing the next industrial revolution, known as Industry 4.0. According to Benešováa, Tupaa (2017) The emerging technology has a big effect on public education. Only qualified and highly educated employees can control thistechnology.

Besides that, Guan, Song \& Li (2018) also said that with the development of science and technology, computers as a learning media have been used widely in every aspect, especially in teaching English. With a combination of computers and English language teaching, teaching in English classes is interesting and no longer boring. Besides that, teaching English with computer media can inspire and motivate students to learn English, optimizing the English classroom environment.

Life skills or innovative skills to live in the industrial revolution era 4.0 consist of leadership, collaboration, creativity, digital literacy, effective communication, emotional intelligence, entrepreneurship, global citizens, problem solving and teamwork. It must also include smart nation building skills or intelligent people who have critical thinking, creativity and innovation, cross-cultural understanding, information and media literacy, careers and learning skills.

Technology development takes an important role in the implementation of education in the era of industrial revolution 4.0. The role of technology supports the teaching and learning process in this digital era because these roles help students to become independent learners. It means that students can learn everything and anywhere by clicking on many features or platforms on the internet that are related to the subjects they are studying. In the learning process of teaching lecturers use many platforms to support their teaching-learning process, the way lecturers provide assignments in which they focus on developing students' skills, and how lecturers assess students. In addition, the lecturers also tried to focus on student-centered learning. Thus, students will be more active and develop their critical thinking towards learning

Blended learning is one solution to address the various needs of Higher Education Institutions throughout the world. Blended Learning is a combination of traditional classrooms and online learning. This learning provides benefits from face-toface learning and electronic learning. The main objective of this study is to assess the effect of blended learning in the teaching process at universities.

Such combinations provide better learning outcomes (Garrison \& Kanuka, 2004). By combining Internet technology and face-to-face interaction can improve 
pedagogy and easier access to information (Bonk \& Graham, 2004). Thus, blended teaching can facilitate an independent and collaborative learning experience. Blended learning builds a community of inquiry and a free and interactive dialogue platform. In addition, Paechter and Maier (2010) referto how students speak in favor of mixed learning. Students who are digitally literate increase the likelihood of extending their lessons and conversations outside the classroom (Kasraie \& Alahmed, 2014).

Increasing technology has changed the behavior and attitudes of students, and has changed the way they learn and communicate inside and outside the classroom. The widespread use of digital technology has changed education. Therefore technology-based learning is needed. Integrating technology with faceto-face instruction can strengthen an interactive and communicative learning environment and provide meaningful learning outcomes (Rooney, 2003; Garrison \& Kanuka, 2004). Fortunately, blended learning is versatile, so it depends on the instructor's decision when it comes to choosing from a variety of choices, depending on the learning context. This paper begins by providing a brief definition of what blended learning is, then discussing why blended learning should be integrated into higher education. The following is a list of challenges facing such an implementation. To conclude, this paper offers some practical ideas about how to integrate technology in higher education.

\section{Research Method}

This research is a qualitative research with the method used in this research is quasi experiment method (quasi experiment). The population in this study was the students of UPI "yptk" Padang academic year 2018/2019. From this population some students are chosen to be the subject of research. Selection of research subjects conducted using Random sampling technique. The subjects of the study were the students of UPI "yptk" Padang In this study, there are two types of instruments used, namely treatment materials in the form of blended learning and data collection instruments. The treatment material used in the study was a study based on blended learning

\section{Result and Discussion}

Students are not only given knowledge, they must be taught different ways of thinking, developing creativity, finding new solutions without help, performing well in standard and nonstandard situations. This change in higher education, in the Bologna Process, represents the transition from centralized transmittal teaching to awareness of added value from the learning process where students have a more active role in increasing knowledge (Monteiro, Leite \& Lima, 2013). Technology helps interaction between lecturers and students in different ways.
They turn the transfer of ordinary knowledge into cooperative learning, activating their creative potential.

Language development in higher education is characterized by the dominance of the internet which enables intensifying traditional teaching forms and methods and thus positively influences the process of mastering foreign languages as a whole. Most higher education institutions use e-learning in the teaching process. Blended learning is a combination of online and face-to-face teaching. According to Krasnova (2015) blended learning can be defined as a teaching method that combines the most effective face-to-face teaching techniques and interactive online collaboration, both of which are systems that function in constant correlation and form a single entity. The system will work effectively only if the components are balanced and methodologically adequate for the educational program goals.

Blended learning is a natural development to the growing accessibility of eLearning, online resources and the continued need for a human component in the learning experience. A blended learning approach ensures that the learner is engaged and driving his or her individual learning experience. This approach also helps cater to the individual needs of the learner, most students have unique learning styles and a blended approach is more likely to cater to those needs than a traditional classroom teaching experience. These are types of blended learning models; (1) Online Instruction occurs via an online platform, with periodic face-to-face meetings. (2) Rotation: Student rotates between self-paced online learning and faceto-face instruction. Schedules are fixed but flexible. (3) Flex: Most instruction is delivered online, with teachers providing as needed support in small-group settings.

(4) Personalized blend: Teacher designs face-to-face and anywhere, anytime learning options that straddle the physical classroom and virtual spaces. Learning is the constant and time is the variable. (5) Online lab: Instructions takes place in a brick and mortar lab. Delivered by an online teacher and supervised onsite by paraprofessionals. (6) Self-blend: Students take online courses to supplement their tradition schools face to face course catalogue. (7) Face-to-face: Teacher offers primarily face-to-face instruction, supplemented with technology in the classroom or computer lab.

Blended learning is important because it breaks down the traditional walls of teaching, ones that don't work for all students and now with access to present day technologies and resources we can tailor the learning experience for each student. Blended learning also offers flexible time frames that can be personalized to each person, offering them the ability to learn at their own pace. The advantages of blended 
learning for teachers; (1) Blended learning offers flexibility in terms of availability - Anytime, anywhere. In other words, eLearning enables the student to access the materials from anywhere at any time. (2) Access to global resources and materials that meet the students' level of knowledge and interest. (3) Self-pacing for slow or quick learners reduces stress, increases satisfaction and information retention. (4) Elearning allows more effective interactions between the learners and their instructors through the use of emails, discussion boards and chat room. (4) Students have the ability to track their progress. (5) Students can also learn through a variety of activities that apply to many different learning styles. (6) E-learning could improve the quality of teaching and learning as it supports the face-to-face teaching approaches. Blended learning also improves other factors for the teacher including; more engaged students, better information and feedback on work, team teaching, extended time with students, more leadership roles, focus on deeper learning, motivate hard to reach kids, new options to teach at home, more earning power, individualized professional development plans.

Blended learning tears down the traditional bricks and mortar approach to teaching, which can improve conditions such as reduced isolation, more opportunities for collaboration, meaningful professional development,better student data, improved time efficiency, role- differentiation. There are advantages of blended learning for students; (1) Increase student interest: when technology is integrated into school lessons, learners are more likely to be interested in, focused on, and excited about the subjects they are studying. Subjects that might be monotonous for some - like math and science, while also increasing information retention. (2) Keep students focused for longer: The use of computers to look up information \& data is a tremendous lifesaver, combined with access to resources such as the internet to conduct research. This engagement and interaction with the resources keeps students focused for longer periods then they would be with books or paper resources, this engagement also helps develop learning through exploration and research. (3). Provides student autonomy: The use of eLearning materials increases a student's ability to set appropriate learning goals and take charge of his or her own learning, which develops an ability that will be translatable across all subjects. (4) Instill a disposition of self-advocacy: Students become self-driven and responsible, tracking their individual achievements, which helps develop the ability to find the resources or get the help they need, self-advocating so they can reach their goals. (5) Promote student ownership: Blended learning instills a sense of 'student ownership over learning' which can be a powerful forcepropelling the learning, It's this feeling of responsibility that helps the feeling of ownership. (6) Allow instant diagnostic information and student feedback: The ability to rapidly analyze, review and give feedback to student work, gives the teacher the ability to tailor his teaching methods and feedback for each student while improving time efficiency. (7) Enables students to learn at their own pace: Due to the flexibility of blended learning and the ability to access internetresources allows students to learn at their own pace, meaning a teacher can help speed up the learning process or give more advanced resources if necessary. (8) Prepares students for the future: Blended learning offers a multitude of real-world skills, that directly translate into life skills, from: research skills, self-learning, selfengagement, helps to develop a 'self-driving force', better decision making, offers a larger sense of responsibility, computer literacy. Blended learning allows students to learn and access material in various modes - important features because students often have very different learning styles (Kaur, 2013). Blended learning makes it possible to vary the speed from a study of new material and selfemployment. For example, for the same text in a foreign language, students can be offered assignments with different levels of difficulty. Weak students have the opportunity to practicesome simple tasks first, while strong students can immediately go to tasks with high complexity.

It is important that students have the possibility of choices that are substantially the basis ofcreativity.

The simple fact that with some activities such as reading books, trying skills in practice, listening to lecturers, and interacting with web-based learning has a significant impact on mastery and retention (Bersin, 2004). The lecturers are very optimistic about blended learning because it adds an extra dimension to learning because the combination of time, space and media offers new possibilities for the types of activities students can do and they can collaborate using available electronic devices (Littlejohn \& Pegler, 2007).

\section{Conclusion}

Although there are indicators that indicate the need that emerges to integrate technology into face-to-face language classes, there are still some limitations that can be the subject of new research. The new generation is equipped with a digital background; thus a mixed learning approach can be very useful because it will improve the quality of learning and improve student access to information. Integrating technology with face-to-face instruction can stimulate learning and provide a more collaborative learning experience. It is time for higher education to adjust to these changes to pursue increasing demands of both 
students and the workplace. Student involvement, motivation and interaction are key factors in achieving a successful learning process. When students can relate what they are learning to real life and personalize it, they become more intrinsically motivated.

\section{References}

[1] Bersin, J. (2004). The Blended Learning Book: Best Practices, Proven Methodologies, and Lessons. San Francisco: John Wiley \& Sons, Inc.

[2] Bonk, C. J. \& Graham, C. R. (Eds.). (in press). Handbook of blended learning: GlobalPerspectives, local designs. San Francisco, CA: Pfeiffer Publishing.

[3] Garrison, R., Vaughan, N. (2008). Blended Learning in Higher Education: Framework, Principles, and Guidelines. San Francisco: John Wiley \& Sons, Inc.

[4] Guan, N,. Song, J,. \& Li, D. (2018). On the Advantages of Computer Multimedia-aidd English Teaching. Procedia Computer Science 131 (2018) 727-732.

[5] Kasraie, N., \& Alahmad, A. (2014). Investigating the reasons institutions of higher education in the USA and Canada utilize blended learning. Mevlana International Journal of Education (MIJE) Vol. 4(1), pp. 67-81, 1 April, 2014 Available online at http://mije.mevlana.edu.tr/http://dx.doi.org/10.13054/m ije.13.68.4.1

[6] Kaur, M. (2013). Blended Learning - its Challenges and Future. 3rd World Conference on Learning, Teaching and Educational Leadership (WCLTA-2012). Procedia Social and Behavioural Sciences 93, 612-617.

[7] Krasnova, T (2015). A Paradigm Shift: Blended Learning Integration in Russian Higher Education. Procedia - Social and Behavioral Sciences 166 (2015) $399-403$

[8] Littlejohn, A., Pegler, C. (2007). Preparing for Blended e-Learning. New York:Routledge.

[9] Monteiro, A., Leite, C., \& Lima, L. (2013). Quality of Blended Learning within theScope of Bologna Process. TOJET: The Turkish Online Journal of Educational Technology, 12 (1), 108-118

[10] Paechter, M. \& Maier, B. (2010). Online or face-toface? Students' experiences and preferences in elearning. Internet and Higher Education. 13, 292-297

[11] Rooney, J. E. (2003). Blending learning opportunities to enhance educational programming and meetings. Association Management, 55(5), 2632.

[12] Tupa, J., Benesovaa, A. (2017). Requirements for Education and Qualification of People in Industry 4.0. Procedia Manufacturing 11 ( 2017 ) 2195-2202 